\title{
The Farmers' Perceptions of Processed Moringa Pudding in Padang Village (Case Study in Padang Village, Manggeng District, Southwest Aceh Regency)
}

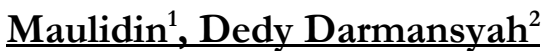 \\ ${ }^{1}$ Agribusiness, Faculty of Agriculture, Universitas Teuku Umar, Meulaboh, Indonesia \\ ${ }^{2}$ Agricultural Socio-Economics, Universitas Teuku Umar, Meulaboh, Indonesia \\ Email: Maulidinmbo24@gmail.com
}

\section{Abstract:}

Moringa is a plant which has a myriad of benefits, Moringa leaves which have complete nutritional content are very good for daily consumption to meet protein for the body, especially children in their infancy. This research was conducted in the village of Padang, Manggeng District, Southwest Aceh Regency, the purpose of this study was to find out how farmers' perceptions of processed Moringa leaf pudding in the village of Padang. From the research results, it is known that farmers' perceptions of processed Moringa leaves can be categorized as good, from the highest total value of the overall research results obtained a perception value of $92.67 \%$, and the lowest value of $82.67 \%$, this value indicates that farmers' perceptions of processed leaves Moringa is good and can be used for food to meet daily nutritional needs. The conclusion drawn in this study is that Moringa is a plant that contains a lot of nutrients that is easy to process as food and has an attractive color and good taste.

Keywords:

moringa; processed; pudding

\section{Introduction}

Moringa Oleifera L commonly known as Moringa leaves is a plant that is also known as the drumstick tree, magic tree, ben oil tree, or radish tree. Moringa is a tree native to India but also grows in Asia, Africa, and South America. Moringa leaves have been used for centuries because the properties of Moringa leaves are so diverse. Moringa has antifungal, antiviral, antidepressant, and anti-inflammatory properties. The content of various substances in Moringa leaves contains protein, vitamins, and minerals contained in Moringa leaves, (Rakha Fahreza, Merdeka. Com, 2021).

Moringa is a plant with a myriad of benefits originating from the Moringaceae tribe. The characteristics of Moringa leaves have a small leaf size, Moringa leaves also have an oval shape and stem. Moringa stems themselves can reach a height of 11 meters with the ends of the branches decorated with fragrant yellow flowers. semerbak. Moringa has the Latin name Morangan Oleifera, Moringa leaves contain vitamins that are believed to have benefits for the health of the body. Moringa plants are plants that can grow anywhere without having to have a special land to cultivate them, these plants can grow along roadsides or in fences, how to plant Moringa stems is very easy just by planting a branch of Moringa stem and then plugging it into the soil. grow. In general, many people still don't know and understand about the efficacy of Moringa leaves, most people only consume Moringa leaves only for a mixture of clear curry, actually Moringa leaves can be used for more than that. There are so many benefits contained in Moringa leaves, but people have not been able to fully utilize them properly. 


\section{Economit Journal: Scientific Journal of Accountancy, Management and Finance ISSN: 2775-5827 (Online), 2775-5819 (Print)}

Vol. 1, No. 4, November 2021, Page: 212-219

Email: economitjournal@gmail.com

Pudding is a kind of food made from starch, which is processed by boiling,steaming, and baking to produce a gel with a soft texture. Starch in this case can be in the form of gelatin or its basic ingredients such as gun arabic, carrageenan seaweed and others, flours or their processed products such as bread, cakes and others. Pudding is one type of dessert or as a dessert served at the end of a banquet. As a dessert, pudding is in great demand because of its sweet taste and soft texture. (Kurniasih, 2013).

Moringa leaf pudding is still foreign among some people as well as people in the village of Padang, although Moringa leaves are easy to find in the area, but people still do not fully understand the nutritional content and preparations obtained from processed Moringa leaves, even people are reluctant to use Moringa leaves on the grounds that they are not like. The nutritional content of Moringa leaves can exceed the nutritional content of carrots, oranges, cow's milk, bananas and yogurt. So from these problems, given the importance of Moringa plants to be used as a food menu or as a dessert to meet the needs of micro protein for body health, Therefore, from this description, the author is interested in examining more deeply the perceptions of farmers on processed Moringa leaves in Padang village through the title of the study entitled "Farmers' perceptions of processed Moringa leaf pudding in Padang Village". Formulation of the problem from the description above, it can be identified the formulation of the problem as follows, what is the perception of farmers on processed Moringa leaf pudding in Padang village.

\section{Relevant Research}

Before this research was conducted there were several studies that had been carried out previously related to this research, including:

Table 1. Results of Previous Research

\begin{tabular}{|c|c|c|c|c|}
\hline No & Researcher & Research Title & Research methods & Results \\
\hline 1. & Nurmalinda & $\begin{array}{l}\text { Housewives' } \\
\text { Perception of } \\
\text { Moringa and its } \\
\text { Process in DKI } \\
\text { Jakarta }\end{array}$ & $\begin{array}{ll}\text { Qualitative and } \\
\text { Qualitative Research }\end{array}$ & $\begin{array}{l}\text { Moringa is widely } \\
\text { known by most } \\
\text { people, and the } \\
\text { public perception of } \\
\text { Moringa and its } \\
\text { preparations is very } \\
\text { good. }\end{array}$ \\
\hline 2. & $\begin{array}{l}\text { Muhammad } \\
\text { Arif Husein }\end{array}$ & $\begin{array}{l}\text { Analysis of } \\
\text { Calcium Content } \\
\text { and Acceptance } \\
\text { Rate of Moringa } \\
\text { Leaf Tea }\end{array}$ & $\begin{array}{l}\text { Experiment with } \\
\text { Completely } \\
\text { Randomized Design } \\
\text { (CRD) }\end{array}$ & $\begin{array}{l}\text { There are differences } \\
\text { in the calcium } \\
\text { content of Moringa } \\
\text { leaf tea and the level } \\
\text { of acceptance of } \\
\text { Moringa leaf tea. }\end{array}$ \\
\hline
\end{tabular}

\section{Review of Literature}

\subsection{Definition of Moringa Plants}

The moringa plant (Morinaga oleifera lam) is known as murong or barunggai, meanwhile, in Sulawesi it is called kero, wari, kelo or keloro and in Java itself is known as moringa is a shrub plant with a height of up to 10 meters, soft and brittle stems, with leaves as big as fingertip shaped egg moon and formed compound. The leaves are pale green with double pinnate leaves with a height of up to 10 meters, soft and brittle stems, with leaves as 
big as fingertip shaped egg moon and formed compound. The leaves are pale green with double pinnate leaves with odd pinnate leaflets and the leaves are oval, the Moringa flowers are panicles that come out of the leaf axils, while the fruit hangs $20-45 \mathrm{~cm}$ long and contains a series of round seeds, but has three wings. Moringa plants flower throughout the year, are white, triangular in shape and about $30 \mathrm{~cm}$ long, thrive from the lowlands to an altitude of 700 $\mathrm{m}$ above sea level, (Kurniasih, 2013).

\subsection{Benefits of Moringa Leaves}

Moringa leaves are the part that contains many benefits. In general, it can be consumed because it contains high nutrition and protein. Traditionally, Moringa leaves are cooked and used like spinach and katuk. Besides being used as a vegetable, Moringa leaves can be dried. Dried Moringa leaves are used as ingredients for Moringa tea, both brewed tea and tea bags and flour or extra Moringa leaves used for filling capsules, Moringa tables, as well as a mixture of nutrients in foodstuffs, such as pudding, ice cream, and various cakes (Kurniasih, 2010). 2013).

\section{Research Methods}

\subsection{Research Sites}

This research was conducted in Padang Village, Manggeng District, and Southwest Aceh Regency. The location of this study was taken intentionally (purposive). The selection of the location was based on the fact that in the village there were many Moringa plants but they were lacking in terms of utilization, therefore the authors chose the research location so that farmers could find out the nutritional content of Moringa plants.

\subsection{Population and Sample}

The population in this study were all farmers in the village of Padang totaling 150 people. Determination of the sample is done using the Slovin formula as follows: $n=\frac{\mathrm{N}}{1+\mathrm{Ne}^{2}}$ Where:

$$
\begin{array}{ll}
\mathrm{N} & =\text { "Population" } \\
\mathrm{n} & =\text { "Sample" } \\
\mathrm{Ne} 2 & =\text { "Error value }(10 \% \text { or } 0.1) "
\end{array}
$$

So the sample in this study was 60 people

\subsection{Data Analysis Method}

Data analysis was carried out qualitatively namely data in the form of words, schematics and images. The qualitative data of this research is the name and address of the object of research and quantitatively the research data in the form of numbers or qualitative data that is numbered.

This method was carried out to calculate the respondents' assessment of the perception of processed Moringa leaf pudding. The analysis used is a Likert scale analysis (Sugiono, 2013), through a score approach of 1-5 as follows: $\frac{\text { ni.si }}{\mathrm{Ni}}$

Where :

ni $=$ "Number of respondents who stated"

$\mathrm{Si}=$ "Score statement"

$\mathrm{Ni}=$ "Number of respondents"(Sugiono, 2013) 
Meanwhile, to assess the perception of processed Moringa leaf pudding, the analysis of the average score was used, with the following formula:

$$
\text { Average score }=\frac{\text { Total Score Earned }}{\text { Maximum value achieved }} X 100 \%
$$

The score categories are as follows:

$$
\begin{aligned}
& 0-33.33=\text { "Not good" } \\
& \text { 33.34-66.7 = "Good enough" } \\
& 66.8-100=\text { "Good". }
\end{aligned}
$$

\section{Discussion}

Moringa is a plant that contains a lot of nutrients, some people have consumed Moringa as a side dish used as a vegetable, but some people are reluctant to consume Moringa leaves because they don't like it. Besides being used as vegetables, Moringa can be processed into pudding which contains rich nutrients, it can be served as a healthy snack for school-age children to meet the nutritional needs of the body. The nutritional content contained in Moringa leaves is, every about two grams of Moringa leaves contains 14 calories and the following various nutrients:

1) 2 grams of protein

2) 1.8 - 2 grams of carbohydrates

3) 0.8 milligrams of iron

4) 8.8 milligrams of magnesium

5) 70 milligrams of potassium

6) 38 - 40 milligrams of calcium

7) 11 milligrams of vitamin $C$

8) $600 \mathrm{IU}$ of vitamin A

9) 8.5 micrograms of folate (Arif Husein, 2017)

In addition to the various nutrients above, Moringa leaves also contain B vitamins, fiber, phosphorus, selenium, zinc, and copper. Moringa leaves also contain lots of antioxidants, such as polyphenols, (dr. Dianan Putri Veronica, 2021). Pudding is a food that has a soft texture and contains lots of fiber which is good for digestion, the soft texture of the pudding gives a fresh effect to the body, and pudding is very good for consumption in hot weather with content that can refresh the body, pudding also contains many nutrients. Moringa leaf pudding with a green appearance like the color of Moringa leaves adds to the appeal in its presentation, adding enough sugar to the processed pudding will give a sweet taste to the Moringa leaf pudding will get a sweet and fresh taste in the pudding, with preparations like this, many people will likes and uses Moringa leaves.

Perception is the result of human assessment of something that is considered good or not good, perception can affect a person's actions or feelings towards an object or perception is said interpretation based on data obtained from the environment that is absorbed by the human senses as taking the initiative of the communication process. According to Jalaludin Rackhmat (2012: 50), Perception is the experience of objects, events or relationships obtained by inferring information and interpreting messages.

Table 2. Farmers' Responses to Moringa Plants

\begin{tabular}{lllllll}
\hline No & Description & $\begin{array}{l}\text { Strongly } \\
\text { disagree }\end{array}$ & $\begin{array}{l}\text { Do } \\
\text { not } \\
\text { agree }\end{array}$ & Neutral & Agree & $\begin{array}{l}\text { Strongly Amount } \\
\text { agree }\end{array}$ \\
& & & \\
\hline
\end{tabular}




\begin{tabular}{|c|c|c|c|c|c|c|c|}
\hline 1. & $\begin{array}{l}\text { I often consume } \\
\text { Moringa leaves }\end{array}$ & 0.0 & 0.06 & 0.70 & 2.00 & 1.16 & 3.92 \\
\hline 2. & $\begin{array}{l}\text { Moringa plants } \\
\text { are in my } \\
\text { garden }\end{array}$ & 0.0 & 0.16 & 0.80 & 1.46 & 1.41 & 3.83 \\
\hline 3. & $\begin{array}{l}\text { I like growing } \\
\text { Moringa plants }\end{array}$ & 0.0 & 0.33 & 0.75 & 2.13 & 0.25 & 3.46 \\
\hline 4. & $\begin{array}{l}\text { I have long } \\
\text { known the } \\
\text { benefits of the } \\
\text { Moringa plant }\end{array}$ & 0.0 & 0.13 & 0.50 & 1.06 & 2.50 & 4.19 \\
\hline 5. & $\begin{array}{l}\text { Moringa plants } \\
\text { are easy to grow } \\
\text { in my village }\end{array}$ & 0.0 & 0.20 & 0.60 & 1.66 & 1.41 & 3.87 \\
\hline \multicolumn{7}{|c|}{ Average } & 3.85 \\
\hline
\end{tabular}

Source: Research Results 2021

From the results of the research in table 2. Respondents have known Moringa plants for a long time, respondents have also often consumed Moringa plants with the results of respondents' responses to the statement agreeing to 2.00. The number of respondents' answers to my point often consume Moringa leaves as much as 3.92. In the second point, there are Moringa plants in my garden, some people in the Padang village have Moringa plants in the respondent's gardens on the statement agreeing as much as 1.46, with the number of answers 3.83. The third point I like to plant Moringa plants, respondents in this study like to plant Moringa plants, the statement agrees as much as 2.13, with the number of answers 3.46. In the fourth point, I have known the benefits of Moringa plants for a long time, at that point 2.50 , with a total of 4.18 answers. In the fifth point, Moringa plants are easy to grow in my village, from the research results, Moringa plants are easy to grow in the respondent's villages with a agreeable statement of 1.66 , with a total number of 3.87 answers. The results obtained from this study with an average value of 3.85 which means that farmers agree that they have known Moringa leaves for a long time, some of the farmers intentionally plant Moringa leaves in their yards or gardens because Moringa plants are very easy to grow.

Table 3. Farmers' Responses to Processed Moringa Leaf Pudding

\begin{tabular}{|c|c|c|c|c|c|c|c|}
\hline No & Description & $\begin{array}{l}\text { Strongly } \\
\text { disagree }\end{array}$ & $\begin{array}{l}\text { Do } \\
\text { not } \\
\text { agree }\end{array}$ & Neutral & Agree & $\begin{array}{l}\text { Strongly } \\
\text { agree }\end{array}$ & Amount \\
\hline 1. & I often consume & 0.0 & 0.13 & 0.53 & 2.33 & 1.08 & 4.07 \\
\hline & $\begin{array}{l}\text { Moringa leaf } \\
\text { pudding }\end{array}$ & & & & & & \\
\hline 2. & $\begin{array}{l}\text { The color of the } \\
\text { Moringa leaf } \\
\text { pudding is very } \\
\text { attractive }\end{array}$ & 0.0 & 0.0 & 0.30 & 1.93 & 2.08 & 4.31 \\
\hline 3. & $\begin{array}{l}\text { I like the taste of } \\
\text { Moringa leaf } \\
\text { pudding }\end{array}$ & 0.0 & 0.0 & 0.20 & 1.50 & 2.16 & 3.86 \\
\hline 4. & $\begin{array}{l}\text { I like to } \\
\text { consume } \\
\text { Moringa leaf } \\
\text { pudding because } \\
\text { it contains a lot }\end{array}$ & 0.0 & 0.16 & 0.50 & 1.66 & 1.66 & 3.98 \\
\hline
\end{tabular}




\begin{tabular}{l} 
5. $\begin{array}{l}\text { of nutrients } \\
\text { My wife/I often } 0.0\end{array}$ \\
serve Moringa \\
leaf pudding for \\
children \\
$\begin{array}{l}\text { The sweet taste } 0.0 \\
\text { of Moringa leaf } \\
\text { pudding makes } \\
\text { me want to enjoy } \\
\text { it again }\end{array}$ \\
$\begin{array}{l}\text { The texture of } 0.0 \\
\text { the Moringa leaf } \\
\text { pudding is very } \\
\text { soft }\end{array}$ \\
\hline Average
\end{tabular}

From the results of the study, it is known that those who provide statements to my description often consume Moringa leaf pudding, some respondents have often consumed Moringa leaf pudding, it is known from the answers of 2.33 respondents who gave agreeable answers, from a total of 4.07 statements. In the description of the second question about the color of Moringa leaf pudding is very interesting, respondents strongly agree that the appearance of the color of Moringa leaf pudding is very attractive, the number of answers in the description is 2.08 with a total of 4.31 answers. In the third description statement about I like the taste of Moringa leaf pudding, respondents like the taste of Moringa leaf pudding from the description who gave a strongly agree answer as much as 2.16 of the total number of answers 3.86. Furthermore, from the description of the statement about I like to consume Moringa leaf pudding because it contains a lot of nutrients, Some respondents like to consume Moringa leaf pudding, it is known from the respondent's statement that agrees is 1.66, and the answer is 1.66 strongly agrees with the number of answers is 3.98. In the description of the next statement about me/my wife often serving moringa leaf pudding for children, some respondents have often served and consumed pudding for their families and children, the number of answers in the statement description was 3.80. The next one who gave a statement about the description of the sweet taste of Moringa leaf pudding made me want to enjoy it again, most of the respondents liked the Moringa leaf pudding because it was sweet, from the results of the answers that the respondents agreed as many as 2.06 of the total number of answers 4.03. In the description of the next statement about the texture of Moringa leaf pudding is very soft, Respondents agreed that the texture of the Moringa leaf pudding was very soft which gave an agreeable answer of 2.66 from the total number of 4.02 answers. From the results of the study in table 3 about the responses of farmers to Moringa leaf pudding, the average respondent's answer was 4.01. Farmers like processed Moringa leaf pudding, because Moringa leaf pudding has a soft texture with a sweet taste and contains nutrients that are beneficial to health.

Table 4. Farmers' Perceptions of Processed Moringa Leaf Pudding

\begin{tabular}{llll}
\hline No & Perception & Perception Level & Score Category \\
\hline 1. & $\begin{array}{l}\text { Moringa leaf pudding is very easy to } \\
\text { make }\end{array}$ & Good \\
2. & $\begin{array}{l}\text { The presentation and color of the } \\
\text { Moringa leaf pudding is very interesting } \\
\text { Consuming processed Moringa leaf } \\
\text { pudding refreshes the body }\end{array}$ & Good \\
\end{tabular}




\begin{tabular}{llll} 
4. & $\begin{array}{l}\text { Processed Moringa leaf pudding } \\
\text { contains a lot of protein and complete } \\
\text { nutrition }\end{array}$ & Good \\
$\begin{array}{l}\text { Processed Moringa leaf pudding can be } \\
\text { stored in the refrigerator for up to a few } \\
\text { days }\end{array}$ & 92.67 & Good \\
\hline Source: Research Results 2021 &
\end{tabular}

From the results of research on farmers' perceptions of processed Moringa leaf pudding, the perception of Moringa leaf pudding is very easy to make, on that perception the perception level is 84.00 , this value meets the value of the good score category scale range. Then the perception of farmers about the presentation and color of the processed Moringa leaf pudding is very interesting, in that perception the perception level is 87.67 , this value meets the value of the good score category scale range. Kemdia on the perception of farmers about consuming processed Moringa leaf pudding refreshes the body, on that perception the perception level is 88.67 , this value meets the value of the good score category scale range. Then on the perception of farmers about Processed Moringa leaf pudding contains a lot of protein and complete nutrition, In this perception, the perception level is 82.67 , this value meets the value of the good score category scale range. Furthermore, the perception of farmers about Processed Moringa leaf pudding can be stored in the refrigerator for up to a few days, on that perception the perception level is 92.67 , this value meets the value of the good score category scale range.

\section{Conclusions}

\subsection{Conclusion}

From the research results, it can be concluded several points related to the title of this research, namely:

1. Moringa leaves (Moringan oleifera) are tropical plants that have long been used by farmers in the village of Padang, Moringa leaves are also easy to grow and can live by planting the stems.

2. Not only used as a mixture of side dishes, Moringa leaves can also be used as pudding as a daily healthy food for most farmers in the Padang village.

3. Moringa leaf pudding has a delicious taste, and has a beautiful color and the texture of Moringa leaf pudding is also soft.

From the overall results of the research, respondents' perceptions of processed Moringa leaf pudding can be categorized as good.

\subsection{Suggestions}

From these conclusions, several points related to the results of the study can be suggested, namely:

1. It is hoped that farmers in Padang Village can make more use of Moringa leaves, not only processed as food, but can be used as food commodities.

2. To be able to know more about the nutritional content and processing methods of Moringa leaves, it is advisable for local village officials to conduct training on Moringa leaf processing.

3. So that if this research can motivate farmers to use Moringa plants better, considering the nutritional content contained in Moringa leaves is very much.

4. In order to carry out socialization about Moringa leaves to farmers more intensively 


\section{References}

Arif Husein, Muhammad. 2017. Analisis Kandungan Kalsium dan Tinkat Penerimaan Teh Daun Kelor. Surakarta.

Diana Putri Veronica. 2021. Alodokter. Kementrian Kesehatan Republik Indonesia. Jakarta. Fahreza Wadya Nanda. Merdeka.Com. 25 Maret 2021.

Jalaludin Rachmat. 2012. Psikologis Komunikasi. Bandung.Remaja Rosdakarya.

Kurniasih, 2013. Khasiat dan Manfaat Daun Kelor. Yogyakarta. Pustaka Baru Press.

Nurmalinda, et al. 2017.Persepsi Ibu Rumah Tangga terhadap Kelor dan Olahannya di DKI Jakarta.Artikel. Jakarta.

Sugiono. 2013. Metode Penelitian. Bandung Alfabeta.

Sugiono. 2016. Metode Penelitian Kuantitatif, Kualitatif dan R\&D. Bandung. Alfabet. 